\title{
Health-care utilization and outcomes of patients at high risk of invasive fungal infection
}

This article was published in the following Dove Press journal:

ClinicoEconomics and Outcomes Research

\author{
Rao Fu' \\ Jake Gundrum' \\ Anita H Sung ${ }^{2}$ \\ 'Premier Applied Sciences, Premier \\ Inc., Charlotte, NC, USA; ${ }^{2}$ Merck \& \\ Co. Inc., Kenilworth, NJ, USA
}

Correspondence: Rao Fu

Premier Applied Sciences, 13034

Ballantyne Corporate Place, Charlotte,

NC 28277, USA

Tel +l 7048164746

Email rao_fu@premierinc.com
Purpose: The objectives of this study were to present trends in posaconazole use over time and describe selected outcomes among patients at high risk of invasive fungal infections (IFIs) by use and type of antifungal medicine.

Methods: A retrospective observational study using data from the Premier Healthcare Database between January 2007 and March 2016 was conducted. Inpatient use of posaconazole by formulation and year is described. Separately, four cohorts of patients at high risk of IFI - those with acute myeloid leukemia (AML), myelodysplastic syndrome (MDS), hematopoietic stem-cell transplantation (HSCT), and graft-vs-host disease (GVHD) - but without a diagnosis code for IFI during the index encounter were identified as potential candidates for antifungal prophylaxis. Use of antifungal medication(s) in these patients was categorized. Index length of stay (LOS), index hospital costs, and subsequent inpatient and outpatient encounters with IFI at 30,60, and 90 days post-index encounter are presented by antifungal group for each cohort. The percentage of patients with inpatient and outpatient encounters with IFI at 90 days post-index encounter was determined for each cohort by year.

Results: Use of posaconazole oral suspension increased through 2012, then declined as the tablet formulation became available in 2013. A total of 19,872 AML patients, 12,125 MDS patients, 14,220 HSCT patients, and 5,431 GVHD patients were considered potential candidates for antifungal prophylaxis; however, a large proportion of patients within each cohort (33\%-94\%) did not receive any antifungal drug during the index hospitalization. Index LOS, hospital costs, and subsequent encounters for IFI varied among cohorts and by antifungal group. Within each cohort, subsequent encounters for IFI at 90 days post-index encounter fluctuated but remained rare across different years.

Conclusion: Over time and as new posaconazole formulations became available, the frequency of use of each formulation changed. In addition, this study suggested a low rate of potential antifungal prophylaxis in high-risk patients. This is one of the first reports attempting to describe antifungal prophylaxis in a contemporary, large, all-payer, geographically representative hospital database.

Keywords: prophylaxis, acute myeloid leukemia, myelodysplastic syndromes, hematopoietic stem-cell transplantation, graft-vs-host disease, health-care outcomes

\section{Introduction}

Patients with acute myeloid leukemia (AML) and myelodysplastic syndrome (MDS) are at high risk for invasive fungal infection (IFI) when presented with prolonged neutropenia after induction chemotherapy. ${ }^{1}$ IFI is associated with increased morbidity and mortality and is a serious concern in AML, MDS, and other immunocompromised 
patients, such as those undergoing hematopoietic stemcell transplantation (HSCT) or with graft-vs-host disease (GVHD). ${ }^{2,3}$ Several professional guidelines recommend using antifungal prophylaxis in high-risk patients and consider timely initiation of antifungal use as a critical component in improving patient outcomes. ${ }^{4-6}$

To date, many antifungal drugs have demonstrated poor efficacy, particularly in the prevention of invasive aspergillosis. The use of fluconazole as prophylaxis is limited by its narrower spectrum of antifungal activity, being effective only against Candida strains. $^{7}$ Voriconazole does not show any significantly greater benefit than other azoles in antifungal prophylaxis..$^{8-10}$ When given in capsules, itraconazole is absorbed poorly, and when given as oral suspension it has gastrointestinal side effects. ${ }^{11}$ Micafungin and caspofungin can only be administered intravenously, are approved only for prophylaxis of Candida infections, and the effectiveness of prophylaxis in hematological patients has not been consistently reported. ${ }^{12-15}$ Finally, unless there are contraindications to use of azole antifungals, amphotericin is not recommended for use as the primary prophylactic treatment. ${ }^{16}$

Posaconazole is a new-generation azole that is recommended for use in neutropenic patients, SCT recipients, and patients with severe GVHD for antifungal prophylaxis by National Comprehensive Cancer Network, American Society of Clinical Oncology, and Infectious Diseases Society of America guidelines. ${ }^{5,7,17}$ Three formulations of posaconazole - oral suspension, delayed-release tablet, and parenteral - are currently US Food and Drug Administration (FDA)-approved for the prophylaxis of invasive Aspergillus and/or Candida infections. In clinical trials, posaconazole has proved to be clinically superior to other triazoles in preventing IFI, especially aspergillosis. ${ }^{17,18}$ Implementation of clinical guidelines and research findings in current practice, however, has not been well followed. Further, real-world evidence leveraging nationwide, geographically representative data to assess associations between posaconazole use and patient outcomes is lacking.

This study set out to describe real-world use of different formulations of posaconazole in a hospital setting. Four cohorts of patients at high risk of IFI - those with AML, MDS, HSCT, and GVHD - and those without diagnosis codes for FI during the index hospitalization were identified as likely candidates for antifungal prophylaxis. Within each cohort, the observed antifungal use was identified and categorized as single (posaconazole or other antifungal), multiple (antifungals with and without posaconazole), or none. Selected economic and clinical outcomes are described for each of the cohorts.

\section{Methods \\ Study design}

A retrospective observational study using the Premier Healthcare Database (PHD) was conducted to describe real-world use of posaconazole in a hospital setting and among patients at high risk of FIs, as well as to explore use of common antifungal drugs and occurrence of IFIs up to 90 days after discharge.

\section{Data source}

The PHD is a large database of geographically diverse US hospitals containing patient- and hospital-level information and representing a variety of payer types. The PHD contains a subset of data from the Premier Quality Advisor platform that offers deidentified, Health Insurance Portability and Accountability Act-compliant data. Use of the PHD data for this study was considered exempt from institutional reviewboard oversight, as dictated by Title 45 Code of Federal Regulations (CFR), Part 46 of the US, specifically 45 CFR 46.101(b)(4) (http://www.hhs.gov/ohrp/humansubjects/ guidance $/ 45 \mathrm{cfr} 46 . \mathrm{html})$. In addition, in accordance with the Health Insurance Portability and Accountability Act privacy rule, data disclosed from the PHD are considered deidentified as per 45 CFR 164.506(d)(2)(ii)(B) through the "expert determination" method.

During the study period, data from standard hospitaldischarge files, including patient demographics, disease states, admission and discharge diagnoses, patient disposition, and discharge status were available from more than 654 million stays, representing more than $20 \%$ of all US hospital discharges. At the time of analyses, there were more than 151 million patients. The PHD also contains a date-stamped log of billed items, including procedures, devices, medications, laboratory tests, and diagnostic and therapeutic services at the individual patient level. Drug-utilization information is available by day of stay and includes quantity, dose, strength, and hospital cost. Patients can be tracked across inpatient and hospital-based outpatient settings, as well as across visits with a unique identifier within a single hospital. Hospital information included geographic location, population served (urban vs rural), teaching status, and number of beds.

\section{Study population}

All patients discharged from an inpatient hospital visit between January 1, 2007 and March 31, 2016 receiving at least one dose of posaconazole, whether used alone or in combination with other antifungals, were identified using medication-billing records in the PHD. The formulation used 
(oral suspension, oral tablet, parenteral) was also identified from the billing records. Since the tablet formulation of posaconazole was approved by the FDA in November 2013 and the parenteral formulation approved in March 2014, any posaconazole used prior to November 2013 was labeled as the oral suspension. If the formulation after November 2013 could not be determined from the billing record, it was classified as an unknown formulation. Trends in use by formulation or use of combinations of posaconazole formulations were displayed over time.

AML patients that did not achieve remission or were in relapse and patients with MDS, HSCT, or GVHD were identified as high-risk population for IFIs and included in the study. For descriptions of antifungal-medication use in the study cohort, all patients discharged from an inpatient hospital visit between January 1, 2007 and March 31, 2016 with a primary diagnosis code for each condition were identified. A hierarchical approach was used to categorize patients into one of the four groups. All patients with a primary ICD9/10 diagnosis code for AML (205.00, 205.02, C92.00, C92.40, C92.50, C92.02, C92.42, or C92.52) who did not meet the criteria for HSCT were categorized into the AML cohort. All patients with a primary ICD9/10 diagnosis code for MDS (238.72-75, D46.0-2, D46.9 or D46.A-C) who did not meet the criteria for HSCT were categorized into the MDS cohort. Patients with a primary ICD9/10 procedure code for HSCT (Table S1) who did not meet the criteria for the GVHD cohort were categorized into the HSCT cohort. Patients with a primary or secondary ICD9/10 diagnosis code for GVHD (279.50-3 or D89.810-3) who also had at least one dose of a selected immunosuppressant drug (methylprednisolone, prednisone, beclomethasone, cyclosporine, sirolimus, tacrolimus, mycophenolate mofetil, thalidomide, methotrexate, azathioprine, pentostatin, infliximab, rituximab, etanercept, methoxsalen, denileukin, antithymocyte globulin, daclizumab, basiliximab, or alemtuzumab) on the hospital medication-billing record were categorized into the GVHD cohort.

For each cohort, the first qualifying visit was identified as the index visit. Patients were then excluded if they had an admission or discharge diagnosis code for an FI during the index visit (ICD9 diagnosis codes 112.XX, 114.X, 115.XX, 116.X, 117.X, 118, 348.89, 484.6, 484.7, 495.4, and 495.6; ICD10 diagnosis codes B36.8, B37.X-B49, H16.069, J67.4, and J67.6). Subsequent inpatient and outpatient encounters in the same hospital system were identified through 90 days after the index visit discharge date.

\section{Antifungal-use groups of interest}

Within each high-risk cohort, patients were further categorized into one of antifungal-use groups based upon the use of antifungal medications during the index visit:

- single antifungal (posaconazole) - the only antifungal used during the index visit was posaconazole

- single antifungal (not posaconazole) - use of only one of fluconazole, itraconazole, voriconazole, micafungin, caspofungin, or amphotericin B during the index visit

- multiple antifungals (including posaconazole) - multiple antifungal drugs listed above were used during index encounter, including posaconazole

- multiple antifungals (not including posaconazole) - multiple antifungal drugs used during the index visit, but none were posaconazole

- no antifungal - no antifungal drugs were used during the index visit

\section{Patient and hospital characteristics}

Selected patient and visit characteristics (age, sex, race, ethnicity, admission type, and discharge status) were obtained from the PHD and are presented by high-risk cohort and antifungal-treatment groups. Selected hospital characteristics (teaching status, urban/rural location, US Census geographical regions, and number of beds) were similarly obtained and are presented in the same manner.

\section{Study outcomes}

Outcomes of interest during the index hospitalization and following discharge from the index hospitalization were determined. Outcomes during index hospitalization were total hospital length of stay (LOS) and total hospital cost. Outcomes following index hospital discharge were the occurrence of 30-, 60-, and 90-day readmissions and subsequent outpatient visits with the presence of a primary or secondary ICD admission or discharge diagnosis code for IFI (Table S2).

\section{Statistical analysis}

Descriptive statistics were derived. Continuous data are expressed as means $\pm \mathrm{SD}$, minimum and maximum, and medians and IQR. Categorical data are expressed as counts and percentages. Patients with missing values for total hospital cost were excluded from cost analysis. Patients who died during the index encounter were excluded from the denominator for analyses of subsequent encounters. 


\section{Results}

\section{Posaconazole use in a hospital setting}

Prior to 2013, the only formulation of posaconazole available in the US was the oral suspension. The number of patients receiving posaconazole oral suspension peaked in 2012 and rapidly declined thereafter (Figure 1). Much of that decline may have resulted from availability of the oral tablet formulation, which demonstrated rapid growth in use in 2014 and 2015. The proportion of inpatients receiving posaconazole who were administered the tablet formulation increased from $24.8 \%$ in 2014 to $62.3 \%$ in the first quarter of 2016 (data not shown), while the proportion of inpatients receiving the oral suspension decreased from $67.5 \%$ to $32.7 \%$ during this same period (data not shown). There was less use of the most recently marketed formulation: parenteral posaconazole. When used, it was frequently prescribed in combination with other formulations during the same hospitalization.

\section{Patient and hospital characteristics of high-risk patients}

Table 1 presents patient and hospital characteristics for each of the four patient cohorts. Table S3 presents patient and hospital characteristics by patient cohort for the five antifungal categories. A total of 51,648 patients who met study criteria

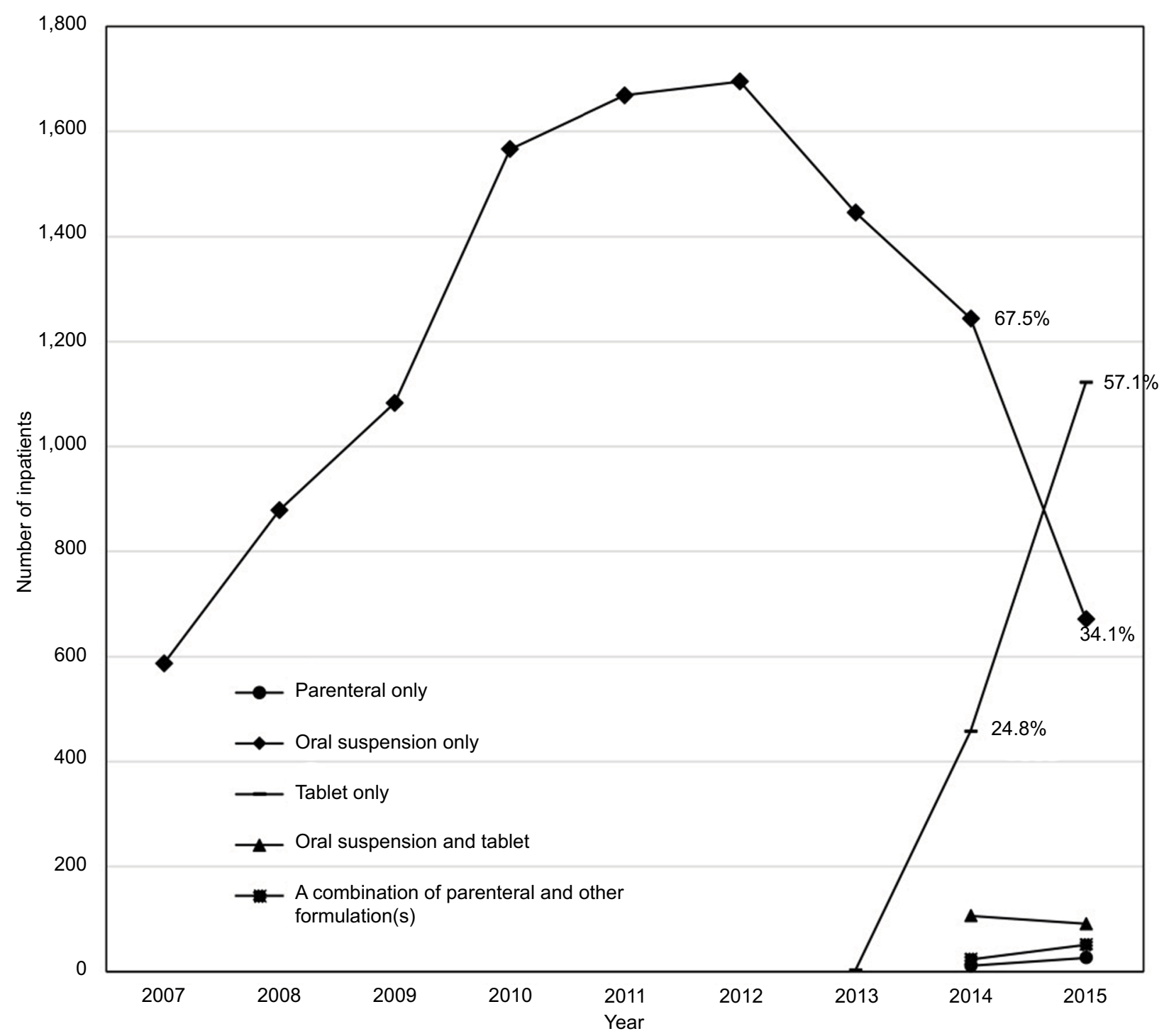

Figure I Inpatients receiving posaconazole by formulation and by year.

Notes: Patients receiving varying formulations of posaconazole during the study years. This graph highlights the declining number of inpatients with posaconazole oral suspension after 2013, when the oral tablet formulation became available. The proportion of inpatients receiving the tablet formulation has increased rapidly in recent years, and parenteral posaconazole was found to have a very small uptake. A total of nine cases from 2014 to the first quarter of 2016 had unknown or unidentifiable formulations. 
Table I Patient, visit, and hospital characteristics of patients with a diagnosis of AML, MDS, HSCT, or GVHD without documented fungal infections

\begin{tabular}{|c|c|c|c|c|c|c|c|c|c|}
\hline & & AML & & MDS & & HSCT & & GVHD & \\
\hline Unique patients & & 19,872 & & 12,125 & & 14,220 & & 5,431 & \\
\hline Unique providers & & 736 & & 753 & & 391 & & 553 & \\
\hline \multirow[t]{5}{*}{ Age, years } & Minimum-maximum & 0 & $85+$ & 0 & $85+$ & 0 & $85+$ & 0 & $85+$ \\
\hline & Mean & 64 & & 76 & & 51 & & 47 & \\
\hline & SD & \pm 19.18 & & \pm 12.75 & & \pm 20.06 & & $\pm|8.7|$ & \\
\hline & Median & 68 & & 79 & & 57 & & 52 & \\
\hline & IQR & 54 & 78 & 70 & 85 & 42 & 65 & 35 & 61 \\
\hline \multirow[t]{6}{*}{ Age-group, years } & $0-17$ & 562 & $2.8 \%$ & 46 & $0.4 \%$ & 1,495 & $10.5 \%$ & 525 & $9.7 \%$ \\
\hline & $18-34$ & 1,317 & $6.6 \%$ & 89 & $0.7 \%$ & 1,256 & $8.8 \%$ & 787 & $14.5 \%$ \\
\hline & $35-44$ & 1,253 & $6.3 \%$ & 118 & $1.0 \%$ & 1,133 & $8.0 \%$ & 626 & $11.5 \%$ \\
\hline & $45-64$ & 5,349 & $26.9 \%$ & I,576 & $13.0 \%$ & 6,429 & $45.2 \%$ & 2,627 & $48.4 \%$ \\
\hline & $65-74$ & 4,770 & $24.0 \%$ & 2,642 & $21.8 \%$ & 3,233 & $22.7 \%$ & 793 & $14.6 \%$ \\
\hline & $75+$ & 6,621 & $33.3 \%$ & 7,654 & $63.1 \%$ & 674 & $4.7 \%$ & 73 & $1.3 \%$ \\
\hline \multirow[t]{3}{*}{ Sex } & Male & 10,922 & $55.0 \%$ & 6,628 & $54.7 \%$ & 8,105 & $57.0 \%$ & 3,139 & $57.8 \%$ \\
\hline & Female & 8,945 & $45.0 \%$ & 5,495 & $45.3 \%$ & 6,115 & $43.0 \%$ & 2,292 & $42.2 \%$ \\
\hline & Unknown & 5 & $0.0 \%$ & 2 & $0.0 \%$ & 0 & $0.0 \%$ & 0 & $0.0 \%$ \\
\hline \multirow[t]{3}{*}{ Race } & White & 14,209 & $71.5 \%$ & 8,938 & $73.7 \%$ & 10,030 & $70.5 \%$ & 4,014 & $73.9 \%$ \\
\hline & Black & 1,917 & $9.6 \%$ & $I,|2|$ & $9.2 \%$ & $\mathrm{I}, 632$ & $11.5 \%$ & 458 & $8.4 \%$ \\
\hline & Other & 3,746 & $18.9 \%$ & 2,066 & $17.0 \%$ & 2,558 & $18.0 \%$ & 959 & $17.7 \%$ \\
\hline \multirow[t]{3}{*}{ Ethnicity } & Not Hispanic or Latino & 9,323 & $46.9 \%$ & 5,805 & $47.9 \%$ & 8,649 & $60.8 \%$ & 3,196 & $58.8 \%$ \\
\hline & Hispanic or Latino & 1,234 & $6.2 \%$ & 662 & $5.5 \%$ & 967 & $6.8 \%$ & 330 & $6.1 \%$ \\
\hline & Other & 9,315 & $46.9 \%$ & 5,658 & $46.7 \%$ & 4,604 & $32.4 \%$ & 1,905 & $35.1 \%$ \\
\hline \multirow[t]{4}{*}{ Admission type } & Urgent/emergent & 16,765 & $84.4 \%$ & 10,456 & $86.2 \%$ & 5,143 & $36.2 \%$ & 3,900 & $71.8 \%$ \\
\hline & Elective & 2,913 & $14.7 \%$ & 1,572 & $13.0 \%$ & 8,992 & $63.2 \%$ & 1,460 & $26.9 \%$ \\
\hline & Trauma & 52 & $0.3 \%$ & 23 & $0.2 \%$ & 4 & $0.0 \%$ & 15 & $0.3 \%$ \\
\hline & Other/Unknown & 142 & $0.7 \%$ & 74 & $0.6 \%$ & 81 & $0.6 \%$ & 56 & $1.0 \%$ \\
\hline \multirow[t]{6}{*}{ Discharge status } & Home & 10,211 & $51.4 \%$ & 8,241 & $68.0 \%$ & 13,184 & $92.7 \%$ & 4,092 & $75.3 \%$ \\
\hline & Transferred & 2,487 & $12.5 \%$ & 335 & $2.8 \%$ & 157 & $1.1 \%$ & 482 & $8.9 \%$ \\
\hline & SNF & 877 & $4.4 \%$ & 2,075 & $17.1 \%$ & 322 & $2.3 \%$ & 192 & $3.5 \%$ \\
\hline & Expired & 3,234 & $16.3 \%$ & 541 & $4.5 \%$ & 318 & $2.2 \%$ & 405 & $7.5 \%$ \\
\hline & Hospice & 2,620 & $13.2 \%$ & 814 & $6.7 \%$ & 91 & $0.6 \%$ & 95 & $1.7 \%$ \\
\hline & Other/unknown & 443 & $2.2 \%$ & 119 & $1.0 \%$ & 148 & $1.0 \%$ & 165 & $3.0 \%$ \\
\hline \multirow[t]{6}{*}{ No. of beds } & $1-149$ & 1,057 & $5.3 \%$ & $\mathrm{I}, 087$ & $9.0 \%$ & 102 & $0.7 \%$ & 223 & $4.1 \%$ \\
\hline & $150-249$ & 2,366 & $11.9 \%$ & 1,942 & $16.0 \%$ & 1,577 & $11.1 \%$ & 679 & $12.5 \%$ \\
\hline & $250-349$ & 2,969 & $14.9 \%$ & 2,312 & $19.1 \%$ & 959 & $6.7 \%$ & 604 & $11.1 \%$ \\
\hline & $350-449$ & 3,372 & $17.0 \%$ & 2,213 & $18.3 \%$ & 1,299 & $9.1 \%$ & 650 & $12.0 \%$ \\
\hline & $450-549$ & 2,747 & $13.8 \%$ & 1,685 & $13.9 \%$ & $\mathrm{I}, 445$ & $10.2 \%$ & 481 & $8.9 \%$ \\
\hline & $550+$ & 7,361 & $37.0 \%$ & 2,886 & $23.8 \%$ & 8,838 & $62.2 \%$ & 2,794 & $51.4 \%$ \\
\hline \multirow[t]{4}{*}{ Geographic region } & West & 3,288 & $16.6 \%$ & $|, 92|$ & $15.8 \%$ & $\mathrm{I}, 543$ & $10.8 \%$ & 778 & $14.3 \%$ \\
\hline & Midwest & 3,581 & $18.0 \%$ & 2280 & $18.8 \%$ & 2397 & $16.9 \%$ & 835 & $15.4 \%$ \\
\hline & Northeast & 3,716 & $18.7 \%$ & 2,425 & $20.0 \%$ & 4,349 & $30.5 \%$ & 1,436 & $26.4 \%$ \\
\hline & South & 9,287 & $46.7 \%$ & 5499 & $45.4 \%$ & 5931 & $41.7 \%$ & 2382 & $43.8 \%$ \\
\hline \multirow[t]{2}{*}{ Teaching } & Yes & 9,405 & $47.3 \%$ & 6,937 & $57.2 \%$ & 3,733 & $26.3 \%$ & 1,933 & $35.6 \%$ \\
\hline & No & 10,467 & $52.7 \%$ & 5,188 & $42.8 \%$ & 10,487 & $73.7 \%$ & 3,498 & $64.4 \%$ \\
\hline \multirow[t]{2}{*}{ Urban/rural } & Rural & 1,350 & $6.8 \%$ & 1,093 & $9.0 \%$ & 396 & $2.8 \%$ & 232 & $4.3 \%$ \\
\hline & Urban & 18,522 & $93.2 \%$ & 11,032 & $91.0 \%$ & 13,824 & $97.2 \%$ & 5,199 & $95.7 \%$ \\
\hline
\end{tabular}

Note: All values are presented as number and percentages unless otherwise designated.

Abbreviations: AML, acute myeloid leukemia; MDS, myelodysplastic syndrome; HSCT, hematopoietic stem-cell transplantation; GVHD, graft-vs-host disease; SNF, skilled nursing facility.

were categorized: 19,872 (38\%) AML patients, 12,125(23\%) MDS patients, 14,220 (28\%) HSCT patients, and 5,431 (11\%) GVHD patients (Table 1). Among these, $58 \%$ of AML patients (11,482), 94\% of MDS patients (11,382), 33\% of HSCT patients $(4,736)$, and $37 \%$ of GVHD patients $(2,014)$ did not receive any of the selected antifungal medications during the index hospitalization (Table S3). Posaconazole, alone or in combination with another drug, was received in $<10 \%$ of patients across the four cohorts.

The median patient age was highest in the MDS cohort (median 79 years, IQR 70-85 years) and lowest in the GVHD cohort (median 52 years, IQR 35-61 years). In each cohort, 
there was a higher proportion of men than women; however, in the subgroup of MDS patients receiving posaconazole plus other antifungals, only $41 \%$ were male. Across all four cohorts, approximately $70 \%$ of patients were white. Approximately $70 \%-85 \%$ of patients with AML, MDS, or GVHD had an emergent or urgent visit, while only $36 \%$ of patients with HSCT had an emergent or urgent visit. Most patients were discharged home, and there were more AML patients transferred to another hospital, hospice, or expired than other cohorts. Consistently across the four cohorts, it appeared that patients receiving posaconazole as the only antifungal during the index encounter had low in-hospital mortality among the five antifungal groups.

More than half of HSCT and GVHD patients were admitted to hospitals with $550+$ beds, while fewer patients with AML (37\%) or MDS (24\%) were treated at such hospitals. With regard to geographical distribution, more patients with HSCT (30\%) and GVHD (26\%) were treated at hospitals in the Northeast than patients with AML (18\%) or MDS $(20 \%)$. Table S3 shows that patients treated with antifungals were more frequently seen in hospitals with 550+ beds than hospitals of smaller sizes. Posaconazole, alone or in combination with another antifungal, was found to be more frequently used in AML, MDS, and GVHD patients in the Northeast and in hospitals with $550+$ beds, which is consistent with the fact that Northeast hospitals tend to have larger bed capacity than other regions in our study sample (data not shown).

The majority of patients with HSCT (73\%) or GVHD (64\%) were treated at teaching hospitals, whereas only around half of or fewer patients with AML (52\%) or MDS (42\%) were treated at teaching hospitals. Across all cohorts and treatment categories (Table S3), over $90 \%$ of patients were admitted to a hospital in an urban area. Overall, antifungal prophylaxis was more frequently given to all four cohorts by teaching hospitals. In both single and multiple antifungal therapies, posaconazole was more frequently given to AML and MDS patients by teaching hospitals.

\section{Economic and clinical outcomes of high- risk patients}

Tables 2-5 present economic and clinical outcomes by antifungal categories for AML, MDS, HSCT, and GVHD cohorts, respectively. Across these four cohorts, patients with no antifungal treatment were found to have the shortest LOS, whereas patients with more than one type of antifungal had the longest LOS. There was not a noticeable difference in LOS between patients treated with posaconazole only and patients treated with one other antifungal only or between patients receiving multiple antifungals treated with and without posaconazole. Consistently, in all four cohorts, patients with no antifungal treatment had the lowest total hospital cost, whereas patients with more than one type of antifungal had the highest. Total hospital costs were similar between patients treated with single antifungals whether posaconazole or other agent; and between patients receiving multiple antifungals whether with or without posaconazole.

IFI-related readmissions and subsequent outpatient visits were rare events. Figure 2 shows that the percentage of patients with subsequent inpatient and outpatient encounters with IFI at 90 days post-index encounter fluctuated yet remained very low over the study period. For each cohort, there was not a noticeable difference across different years. Patients with no antifungal treatment had the fewest IFIrelated readmissions and subsequent outpatient visits, and no remarkable differences were found among the remaining four treatment groups (Tables 2-5).

\section{Discussion}

Antifungal prophylaxis for high-risk patients has been promoted by various scientific societies due to the rising incidence of life-threatening IFIs and undesired outcomes when initiation of antifungal use is delayed. ${ }^{19}$ This is one of the first studies to observe and characterize the possible use of antifungal prophylaxis and associated outcomes in a large, representative database. Our findings indicate that across different cohorts of immunocompromised patients, antifungal prophylaxis appears to be underutilized, especially in patients with shorter hospital stays. As patient LOS extended, a greater proportion of the at-risk population started to receive multiple antifungal drugs, even when no FI was present. Although antifungal prophylaxis is currently regarded as the gold standard in situations with a high risk of FI, such as in these immunocompromised patients, ${ }^{4,5,7,9}$ it is possible that the clinician's perspective of risk for an individual patient may vary and/or there may be inconsistency in the interpretation and application of guideline recommendations for antifungal prophylaxis. $^{20}$

The unexpected finding that a substantial number of highrisk patients did not receive antifungal prophylaxis highlights the need for initiatives to promote the adoption of guideline recommendations. The higher proportion of patients receiving antifungal prophylaxis within teaching hospitals may indicate greater knowledge, receptivity, and/or availability of tools for utilization of antifungal prophylaxis or could be due to the fact that teaching hospitals may contain a higher proportion of complex patients considered at extremely high 


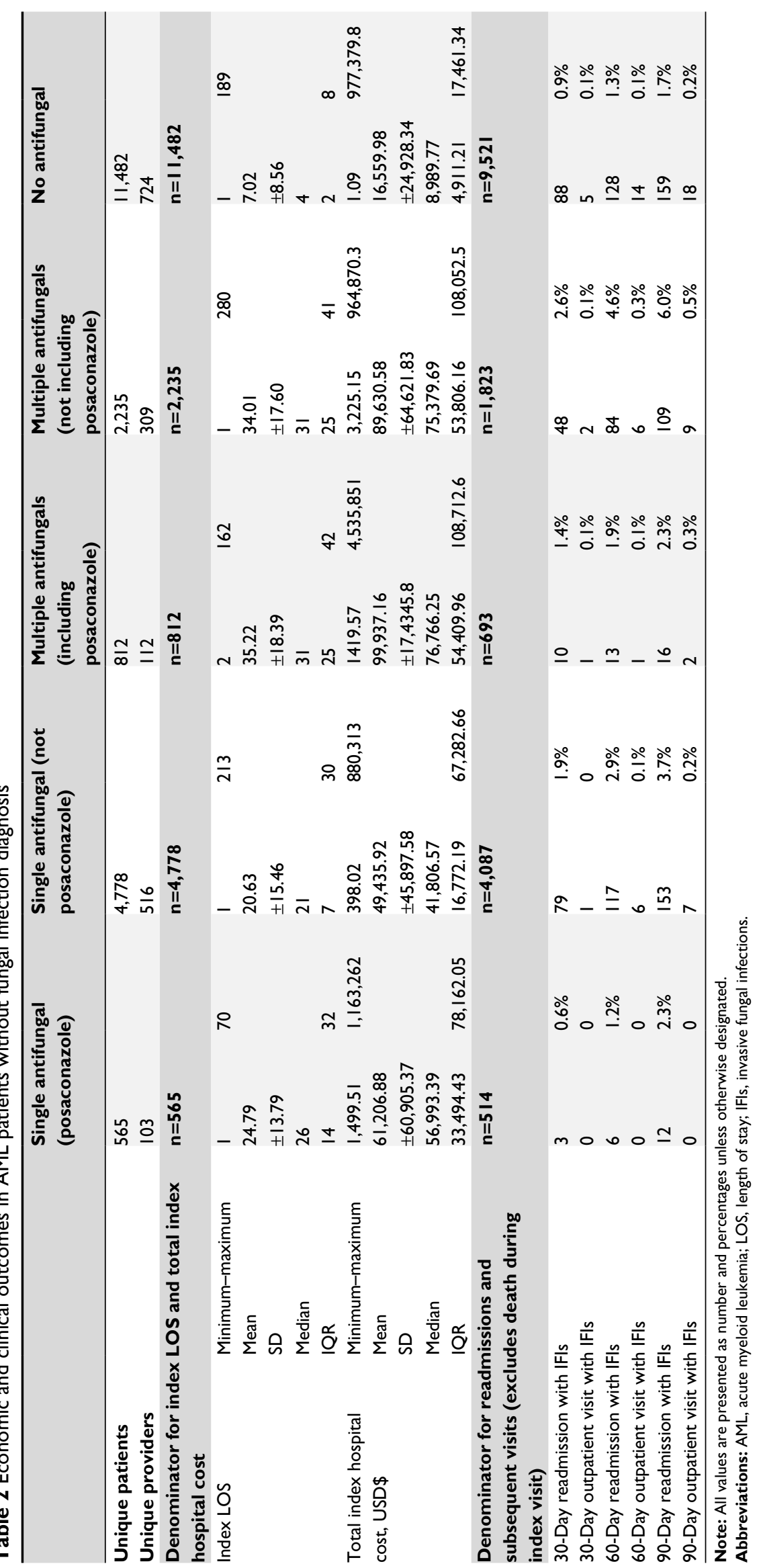




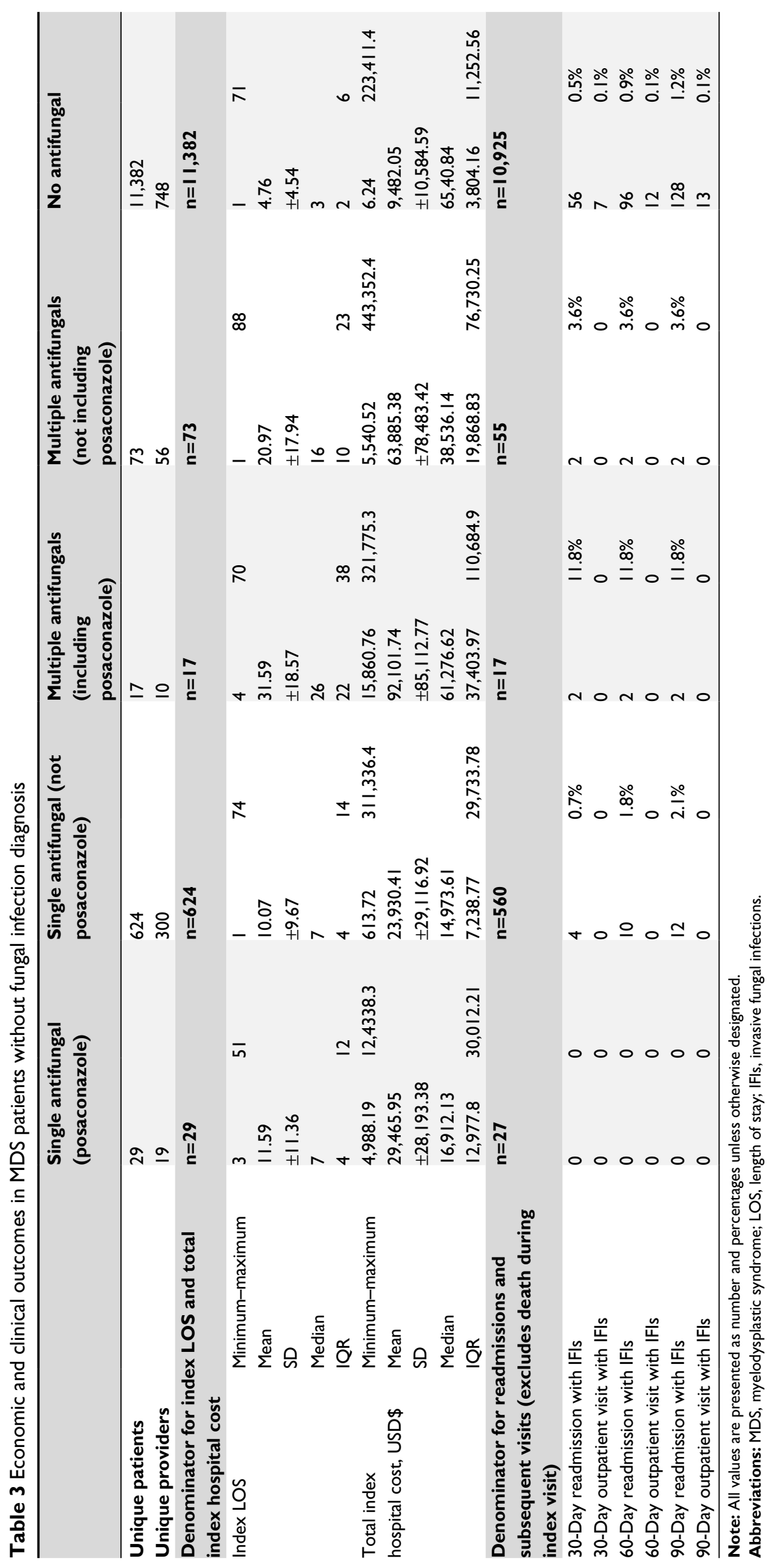




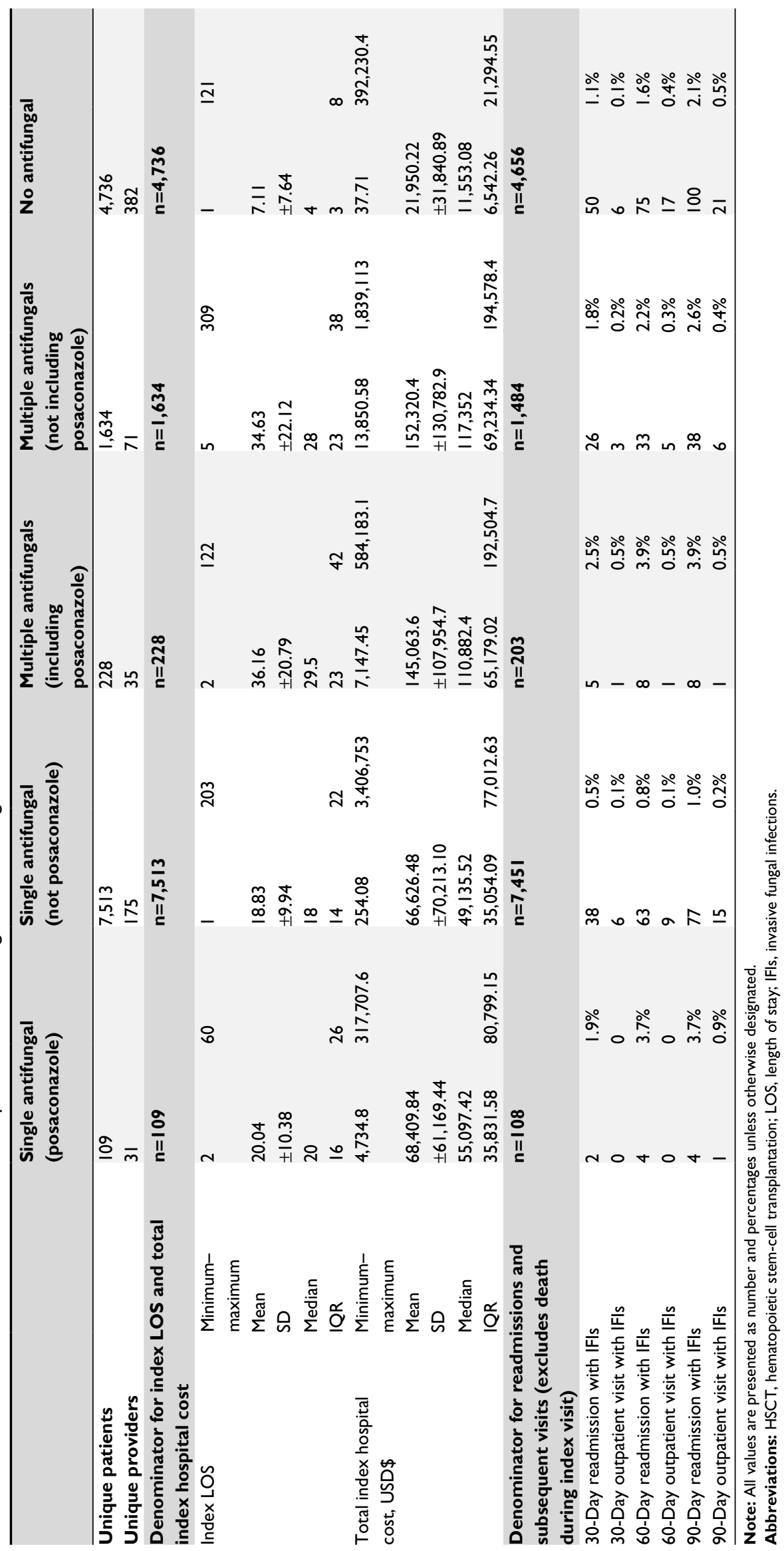




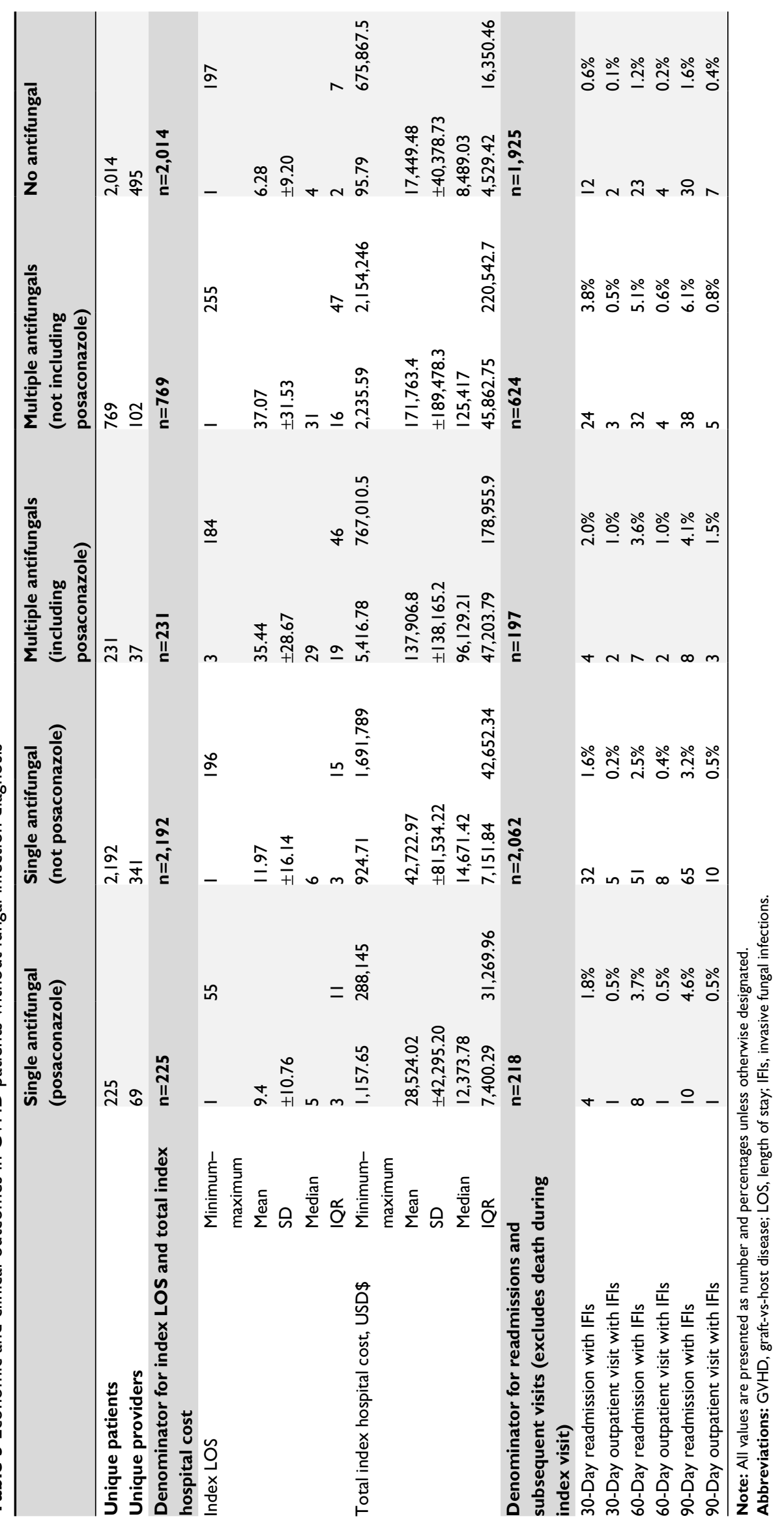




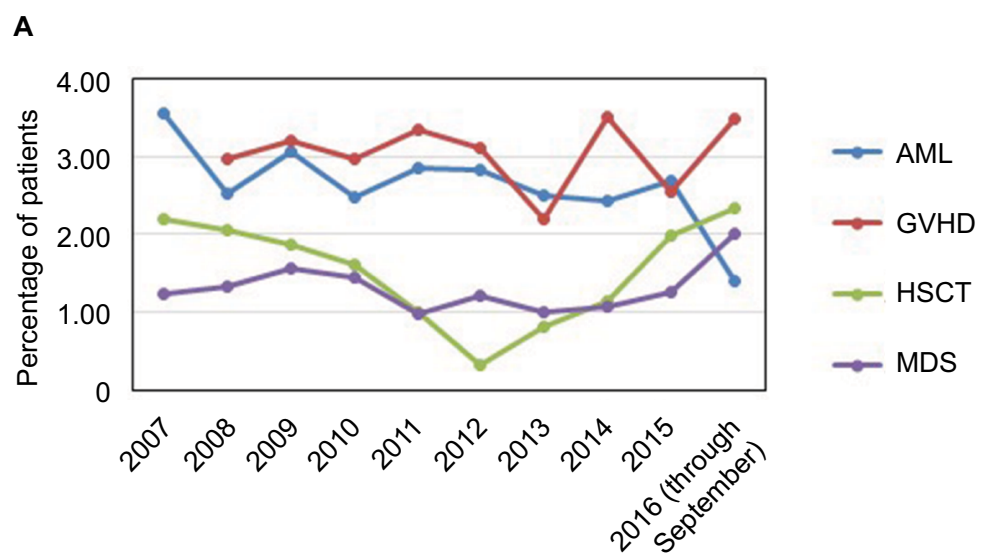

Discharge year of the index hospitalization

B

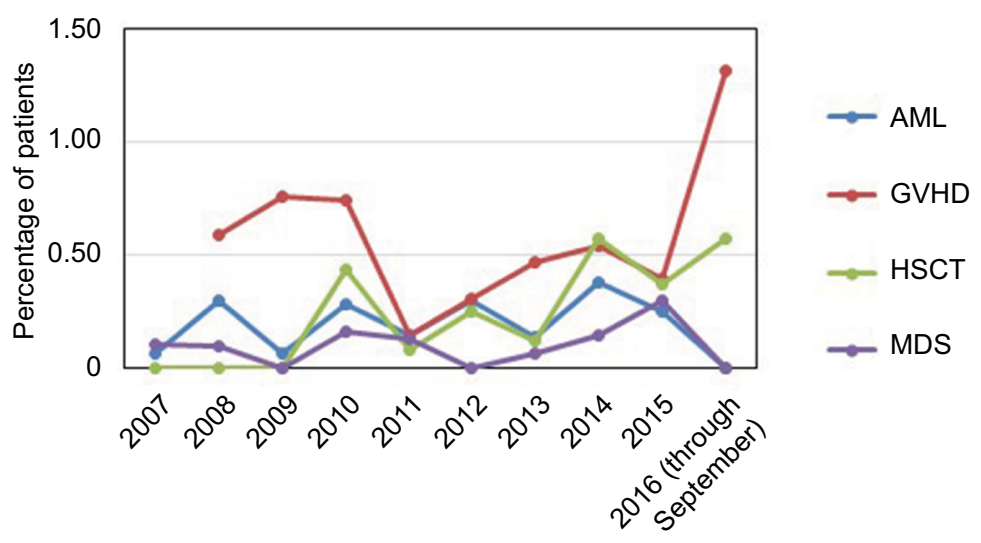

Discharge year of the index hospitalization

Figure 2 Inpatients with 90-day subsequent inpatient (A) and outpatient visits (B) with IFI by cohort and by year.

Notes: There was no noticeable trend over time, and patients with 90-day IFI-related subsequent inpatient and outpatient visits appeared to be rare across the four study cohorts. No GVHD encounters in 2007 met the study-inclusion criteria; therefore, readmissions and outpatient visits were not presented for the GVHD cohort in 2007. Abbreviations: AML, acute myeloid leukemia; GVHD, graft-vs-host disease; HSCT, hematopoietic stem-cell transplantation; IFI, invasive fungal infection; MDS, myelodysplastic syndrome.

risk of FIs. Regional differences may also indicate varying degrees of knowledge, receptivity, and available resources. Additional investigations may facilitate a better understanding of clinician decision-making and guide development of tools for greater use of antifungal prophylaxis in appropriate patients across all hospitals in the nation.

There are a number of limitations to this study. First, the identification of antifungals was based on text-string searching in hospitals' charge masters. Since hospitals record their pharmacy costs in a variety of ways, some discharges that used an antifungal of interest may not have been captured. Second, due to the retrospective nature of this study and lack of access to medical records, it was extremely difficult to differentiate antifungal prophylaxis from treatment or empirical treatment. One important assumption of the study was that patients with antifungal use who did not have any diagnosis for an FI were likely receiving the antifungal(s) for prophylaxis. Under this assumption, those who received antifungal prophylaxis in the beginning of their stay but later developed an FI were not a focus of this study, and addition of this subset of patients in future studies could lead to different conclusions. Third, the risk of IFI and corresponding therapeutic strategies to address IFI were not constant during all the phases of treatment of the four cohorts. For example, since induction chemotherapy is the first time that a patient experiences profound immunosuppression, most $\mathrm{AML}$ patients are at greater risk of IFI at this stage, but differentiations of the treatment stage of each patient were not included in this study. Fourth, patients discharged from January 1, 2007 to March 30, 2007 may have had a hospitalization dur- 
ing the 90 days prior to their index hospitalization, raising a possibility, albeit small, that some readmissions might be misclassified. It is also important to note that this US study may not be generalizable to other health-care settings. Lastly, the current study design was descriptive. No unadjusted or adjusted comparisons were made.

\section{Conclusion}

To date, there has been limited retrospective research using a large, all-payer, geographically representative hospital database to describe high-risk patients who require antifungal prophylaxis. This current study, despite its limitations, adds real-world knowledge to this field. The results revealed that contrary to guideline recommendations, some high-risk patients did not receive any antifungal prophylaxis. Additional research is necessary to confirm this finding and determine reasons for potential underutilization of antifungal prophylaxis in high-risk patients, in order to develop interventions and tools to improve guideline adherence and clinical outcomes.

\section{Acknowledgments}

The authors wish to acknowledge Carol Cohen, who provided editorial support for the manuscript, and also Hetty Waskin and Michael Westmoreland for their invaluable clinical insights that significantly enhanced the manuscript.

\section{Disclosure}

RF and JG are employees of Premier, which received funding from Merck for conducting this study. AHS was formerly with Merck \& Co., Inc. The authors declare no other conflicts of interest in this work.

\section{References}

1. Rüping MJ, Vehreschild JJ, Cornely OA. Patients at high risk of invasive fungal infections: when and how to treat. Drugs. 2008;68(14): 1941-1962.

2. Fleming S, Yannakou CK, Haeusler GM, et al. Consensus guidelines for antifungal prophylaxis in haematological malignancy and haemopoietic stem cell transplantation, 2014. Intern Med J. 2014;44(12B):1283-1297.

3. Marr KA, Bow E, Chiller T, et al. Fungal infection prevention after hematopoietic cell transplantation. Bone Marrow Transplant. 2009;44(8):483-487.
4. Flowers CR, Seidenfeld J, Bow EJ, et al. Antimicrobial prophylaxis and outpatient management of fever and neutropenia in adults treated for malignancy: American Society of Clinical Oncology clinical practice guideline. J Clin Oncol. 2013;31(6):794-810.

5. Freifeld AG, Bow EJ, Sepkowitz KA, et al. Clinical practice guideline for the use of antimicrobial agents in neutropenic patients with cancer: 2010 update by the Infectious Diseases Society of America. Clin Infect Dis. 2011;52(4):e56-e93.

6. Baden LR, Bensinger W, Angarone M, et al. Prevention and treatment of cancer-related infections. J Natl Compr Canc Netw. 2012;10(11):1412-1445.

7. Pappas PG, Kauffman CA, Andes DR, et al. Clinical practice guideline for the management of candidiasis: 2016 update by the Infectious Diseases Society of America. Clin Infect Dis. 2016;62(4):e1-e50.

8. Cornely OA, Maertens J, Winston DJ, et al. Posaconazole vs. fluconazole or itraconazole prophylaxis in patients with neutropenia. $N$ Engl J Med. 2007;356(4):348-359.

9. Tacke D, Buchheidt D, Karthaus M, et al. Primary prophylaxis of invasive fungal infections in patients with haematologic malignancies: 2014 update of the recommendations of the Infectious Diseases Working Party of the German Society for Haematology and Oncology. Ann Hematol. 2014;93(9):1449-1456.

10. Vehreschild JJ, Böhme A, Buchheidt D, et al. A double-blind trial on prophylactic voriconazole (VRC) or placebo during induction chemotherapy for acute myelogenous leukaemia (AML). J Infect. 2007;55(5):445-449.

11. Nucci M, Biasoli I, Akiti T, et al. A double-blind, randomized, placebocontrolled trial of itraconazole capsules as antifungal prophylaxis for neutropenic patients. Clin Infect Dis. 2000;30(2):300-305.

12. Scott LJ. Micafungin: a review of its use in the prophylaxis and treatment of invasive Candida infections. Drugs. 2012;72(16):2141-2165.

13. Hiramatsu Y, Maeda Y, Fujii N, et al. Use of micafungin versus fluconazole for antifungal prophylaxis in neutropenic patients receiving hematopoietic stem cell transplantation. Int J Hematol. 2008;88(5):588-595.

14. Hirata Y, Yokote T, Kobayashi K, et al. Antifungal prophylaxis with micafungin in neutropenic patients with hematological malignancies. Leuk Lymphoma. 2010;51(5):853-859.

15. Neofytos D, Huang YT, Cheng K, et al. Safety and efficacy of intermittent intravenous administration of high-dose micafungin. Clin Infect Dis. 2015;61 Suppl 6:S652-S661.

16. Uzun O, Anaissie EJ. Antifungal prophylaxis in patients with hematologic malignancies: a reappraisal. Blood. 1995;86(6):2063-2072.

17. Soysal A. Prevention of invasive fungal infections in immunocompromised patients: the role of delayed-release posaconazole. Infect Drug Resist, 2015. 8:321-31.

18. Ullmann AJ, Lipton JH, Vesole DH, et al. Posaconazole or fluconazole for prophylaxis in severe graft-versus-host disease. $N$ Engl $J$ Med. 2007;356(4):335-347.

19. Boutati EI, Anaissie EJ. Fusarium, a significant emerging pathogen in patients with hematologic malignancy: ten years' experience at a cancer center and implications for management. Blood. 1997;90(3):999-1008.

20. Sung AH, Rhodes T, Arduino J, et al. Inconsistency in defining profound and prolonged neutropenia for antifungal prophylaxis decisions. Poster presented at: ICAAC-ICC 2015; September 17-21, 2015; San Diego, CA. 


\section{Supplementary material}

Table SI Primary ICD9/I0 procedure code for hematopoietic stem-cell transplantation

ICD9: 4I.0X

ICDI0: 30230AZ, 30230G0, 30230GI, 30230X0, 30230XI, 30230Y0, 30230YI, 30233AZ, 30233G0, 30233GI, 30233X0, 30233XI, 30233Y0,

30233YI, 30240AZ, 30240G0, 30240GI, 30240X0, 30240XI, 30240Y0, 30240YI, 30243AZ, 30243G0, 30243GI, 30243X0, 30243XI, 30243Y0, 30243YI, 30250G0, 30250GI, 30250X0, 30250XI, 30250Y0, 30250YI, 30253G0, 30253GI, 30253X0, 30253XI, 30253Y0, 30253YI, 30260G0, 30260GI, 30260X0, 30260XI, 30260Y0, 30260YI, 30263G0, 30263GI, 30263X0, 30263XI, 30263Y0, 30263YI, 3E03005, 3E03305, 3E04005, 3E04305, 3E05005, 3E05305, 3E06005, or 3E06305

Table S2 Primary or secondary ICD admission or discharge diagnosis code for invasive fungal infection

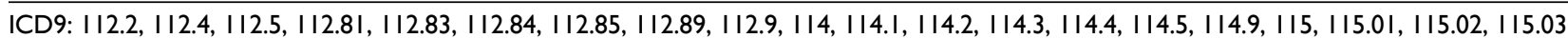
II5.04, II5.05, II5.09, II5.II, II5.I2, II5.I3, II5.I4, II5.I5, II5.19, II5.9I, II5.92, II5.93, II5.94, II5.95, II5.99, II6, II6.I, II7.I, II7.2, II7.3, II $7.5,117.6,117.7,117.8,117.9,118,348.89,484.6,484.7,495.4$ or 495.6

ICD-I0: B37.I, B37.4I, B37.49, B37.5, B37.6, B37.7, B37.8I, B37.82, B37.89, B37.9, B38.0, B38.I, B38.2, B38.4, B38.7, B38.8I, B38.89, B38.9, B39.0, B39.I, B39.2, B39.3, B39.4, B39.5, B39.9, B40.0, B40.I, B40.2, B40.7, B40.8I, B40.89, B40.9, B4I.0, B4I.7, B4I.8, B4I.9, B42.0, B42.I, B42.7, B42.8I, B42.89, B42.9, B43.I, B43.2, B43.8, B43.9, B44.0, B44.I, B44.7, B44.8I, B44.89, B44.9, B45.0, B45.I, B45.3, B45.7, B45.8, B45.9, B46.0, B46.I, B46.2, B46.4, B46.5, B46.8, B46.9, B47.0, B47.I, B48.2, B48.3, B48.4, B48.8, B49, G93.89, HI6.069, J67.4 or J67.6

Table S3 Patient, visit, and hospital characteristics by antifungal use

\begin{tabular}{|c|c|c|c|c|c|c|c|c|c|c|c|}
\hline \multirow[t]{2}{*}{$\begin{array}{l}\text { AML } \\
\text { Unique patients }\end{array}$} & & \multicolumn{2}{|c|}{$\begin{array}{l}\text { Single } \\
\text { antifungal } \\
\text { (posaconazole) }\end{array}$} & \multicolumn{2}{|c|}{$\begin{array}{l}\text { Single } \\
\text { antifungal } \\
\text { (not } \\
\text { posaconazole) }\end{array}$} & \multicolumn{2}{|c|}{$\begin{array}{l}\text { Multiple } \\
\text { antifungals } \\
\text { (including } \\
\text { posaconazole) }\end{array}$} & \multicolumn{2}{|c|}{$\begin{array}{l}\text { Multiple } \\
\text { antifungals } \\
\text { (not including } \\
\text { posaconazole) }\end{array}$} & \multicolumn{2}{|c|}{$\begin{array}{l}\text { No } \\
\text { antifungal }\end{array}$} \\
\hline & & 565 & & 4,778 & & 812 & & 2,235 & & 11,482 & \\
\hline Unique providers & & 103 & & 516 & & 112 & & 309 & & 724 & \\
\hline \multirow[t]{5}{*}{ Age, years } & $\begin{array}{l}\text { Minimum- } \\
\text { maximum }\end{array}$ & 0 & $85+$ & 0 & $85+$ & 5 & $85+$ & 0 & $85+$ & 0 & $85+$ \\
\hline & Mean & 57 & & 58 & & 56 & & 54 & & 69 & \\
\hline & SD & \pm 16.35 & & \pm 19.88 & & \pm 15.52 & & \pm 18.33 & & \pm 17.72 & \\
\hline & Median & 60 & & 63 & & 59 & & 58 & & 73 & \\
\hline & IQR & 47 & 69 & 48 & 73 & 45 & 68 & 44 & 67 & 61 & 81 \\
\hline \multirow[t]{6}{*}{ Age-group, years } & $0-17$ & 9 & $1.6 \%$ & 246 & $5.1 \%$ & 4 & $0.5 \%$ & 118 & $5.3 \%$ & 185 & $1.6 \%$ \\
\hline & $18-34$ & 51 & $9.0 \%$ & 397 & $8.3 \%$ & 91 & $11.2 \%$ & 243 & $10.9 \%$ & 535 & $4.7 \%$ \\
\hline & $35-44$ & 66 & $11.7 \%$ & 373 & $7.8 \%$ & 96 & $11.8 \%$ & 208 & $9.3 \%$ & 510 & $4.4 \%$ \\
\hline & $45-64$ & 231 & $40.9 \%$ & $|, 57|$ & $32.9 \%$ & 353 & $43.5 \%$ & 940 & $42.1 \%$ & 2,254 & $19.6 \%$ \\
\hline & $65-74$ & 134 & $23.7 \%$ & 1,189 & $24.9 \%$ & 195 & $24.0 \%$ & 531 & $23.8 \%$ & 2,721 & $23.7 \%$ \\
\hline & $75+$ & 74 & $13.1 \%$ & 1,002 & $21.0 \%$ & 73 & $9.0 \%$ & 195 & $8.7 \%$ & 5,277 & $46.0 \%$ \\
\hline \multirow[t]{3}{*}{ Sex } & Male & 334 & $59.1 \%$ & 2,662 & $55.7 \%$ & 398 & $49.0 \%$ & 1,191 & $53.3 \%$ & 6,337 & $55.2 \%$ \\
\hline & Female & 231 & $40.9 \%$ & 2,115 & $44.3 \%$ & 414 & $51.0 \%$ & 1,042 & $46.6 \%$ & 5,143 & $44.8 \%$ \\
\hline & Unknown & 0 & 0 & 1 & 0 & 0 & 0 & 2 & $0.1 \%$ & 2 & 0 \\
\hline \multirow[t]{3}{*}{ Race } & White & 398 & $70.4 \%$ & 3,327 & $69.6 \%$ & 600 & $73.9 \%$ & 1,517 & $67.9 \%$ & 8,367 & $72.9 \%$ \\
\hline & Black & 46 & $8.1 \%$ & 469 & $9.8 \%$ & 77 & $9.5 \%$ & 237 & $10.6 \%$ & 1,088 & $9.5 \%$ \\
\hline & Other & 121 & $21.4 \%$ & 982 & $20.6 \%$ & 135 & $16.6 \%$ & 481 & $21.5 \%$ & 2,027 & $17.7 \%$ \\
\hline \multirow[t]{3}{*}{ Ethnicity } & $\begin{array}{l}\text { Not Hispanic or } \\
\text { Latino }\end{array}$ & 310 & $54.9 \%$ & 2,139 & $44.8 \%$ & 459 & $56.5 \%$ & 1,036 & $46.4 \%$ & 5,379 & $46.8 \%$ \\
\hline & Hispanic or Latino & 52 & $9.2 \%$ & 348 & $7.3 \%$ & 56 & $6.9 \%$ & 159 & $7.1 \%$ & 619 & $5.4 \%$ \\
\hline & Other & 203 & $35.9 \%$ & 2,291 & $47.9 \%$ & 297 & $36.6 \%$ & 1,040 & $46.5 \%$ & 5,484 & $47.8 \%$ \\
\hline \multirow[t]{4}{*}{ Admission type } & Urgent/emergent & 464 & $82.1 \%$ & 3,896 & $81.5 \%$ & 639 & $78.7 \%$ & 1,840 & $82.3 \%$ & 9,926 & $86.4 \%$ \\
\hline & Elective & 91 & $16.1 \%$ & 847 & $17.7 \%$ & $15 \mid$ & $18.6 \%$ & 375 & $16.8 \%$ & 1,449 & $12.6 \%$ \\
\hline & Trauma & 0 & 0 & 13 & $0.3 \%$ & 1 & $0.1 \%$ & 8 & $0.4 \%$ & 30 & $0.3 \%$ \\
\hline & Other/unknown & 10 & $1.8 \%$ & 22 & $0.5 \%$ & 21 & $2.6 \%$ & 12 & $0.5 \%$ & 77 & $0.7 \%$ \\
\hline
\end{tabular}


Table S3 (Continued)

\begin{tabular}{|c|c|c|c|c|c|c|c|c|c|c|c|}
\hline \multirow{2}{*}{$\begin{array}{l}\text { AML } \\
\text { Discharge status }\end{array}$} & \multirow[b]{2}{*}{ Home } & \multicolumn{2}{|c|}{$\begin{array}{l}\text { Single } \\
\text { antifungal } \\
\text { (posaconazole) }\end{array}$} & \multicolumn{2}{|c|}{$\begin{array}{l}\text { Single } \\
\text { antifungal } \\
\text { (not } \\
\text { posaconazole) } \\
\end{array}$} & \multicolumn{2}{|c|}{$\begin{array}{l}\text { Multiple } \\
\text { antifungals } \\
\text { (including } \\
\text { posaconazole) }\end{array}$} & \multicolumn{2}{|c|}{$\begin{array}{l}\text { Multiple } \\
\text { antifungals } \\
\text { (not including } \\
\text { posaconazole) }\end{array}$} & \multicolumn{2}{|c|}{$\begin{array}{l}\text { No } \\
\text { antifungal }\end{array}$} \\
\hline & & 440 & $77.9 \%$ & 3,093 & $64.7 \%$ & 592 & $72.9 \%$ & $\mathrm{I}, 480$ & $66.2 \%$ & 4,606 & $40.1 \%$ \\
\hline & Transferred & 19 & $3.4 \%$ & 356 & $7.5 \%$ & 28 & $3.4 \%$ & 105 & $4.7 \%$ & 1,979 & $17.2 \%$ \\
\hline & SNF & 15 & $2.7 \%$ & 166 & $3.5 \%$ & 27 & $3.3 \%$ & 75 & $3.4 \%$ & 594 & $5.2 \%$ \\
\hline & Expired & 51 & $9.0 \%$ & 691 & $14.5 \%$ & 119 & $14.7 \%$ & 412 & $18.4 \%$ & $|, 96|$ & $17.1 \%$ \\
\hline & Hospice & 31 & $5.5 \%$ & 393 & $8.2 \%$ & 33 & $4.1 \%$ & 138 & $6.2 \%$ & 2,025 & $17.6 \%$ \\
\hline & Other/unknown & 9 & $1.6 \%$ & 79 & $1.7 \%$ & 13 & $1.6 \%$ & 25 & $1.1 \%$ & 317 & $2.8 \%$ \\
\hline \multirow[t]{6}{*}{ No. of beds } & $1-149$ & 2 & $0.4 \%$ & 140 & $2.9 \%$ & 1 & $0.1 \%$ & 29 & $1.3 \%$ & 885 & $7.7 \%$ \\
\hline & $150-249$ & 7 & $1.2 \%$ & 492 & $10.3 \%$ & 37 & $4.6 \%$ & 229 & $10.2 \%$ & $|, 60|$ & $13.9 \%$ \\
\hline & $250-349$ & 60 & $10.6 \%$ & 625 & $13.1 \%$ & 104 & $12.8 \%$ & 220 & $9.8 \%$ & 1,960 & $17.1 \%$ \\
\hline & $350-449$ & 119 & $21.1 \%$ & 661 & $13.8 \%$ & 134 & $16.5 \%$ & 255 & $11.4 \%$ & 2,203 & $19.2 \%$ \\
\hline & $450-549$ & 34 & $6.0 \%$ & 738 & $15.4 \%$ & 36 & $4.4 \%$ & 324 & $14.5 \%$ & 1,615 & $14.1 \%$ \\
\hline & $550+$ & 343 & $60.7 \%$ & 2,122 & $44.4 \%$ & 500 & $61.6 \%$ & 1,178 & $52.7 \%$ & 3,218 & $28.0 \%$ \\
\hline \multirow[t]{4}{*}{ Geographic region } & West & 44 & $7.7 \%$ & 807 & $16.9 \%$ & 53 & $6.5 \%$ & 338 & $15.1 \%$ & 2,046 & $17.8 \%$ \\
\hline & Midwest & 55 & $9.8 \%$ & 737 & $15.5 \%$ & 87 & $10.7 \%$ & 372 & $16.7 \%$ & 2,330 & $20.3 \%$ \\
\hline & Northeast & 183 & $32.4 \%$ & 817 & $17.1 \%$ & 196 & $24.1 \%$ & 405 & $18.2 \%$ & 2,115 & $18.4 \%$ \\
\hline & South & 283 & $50.1 \%$ & 2417 & $50.7 \%$ & 476 & $58.7 \%$ & 1120 & $50.2 \%$ & 4,991 & $43.5 \%$ \\
\hline \multirow[t]{2}{*}{ Teaching } & Yes & 156 & $27.6 \%$ & 2,133 & $44.6 \%$ & 187 & $23.0 \%$ & 819 & $36.6 \%$ & 6,110 & $53.2 \%$ \\
\hline & No & 409 & $72.4 \%$ & 2,645 & $55.4 \%$ & 625 & $77.0 \%$ & 1,416 & $63.4 \%$ & 5,372 & $46.8 \%$ \\
\hline \multirow[t]{2}{*}{ Urban/rural } & Rural & 6 & $1.1 \%$ & 244 & $5.1 \%$ & $\mathrm{II}$ & $1.4 \%$ & 82 & $3.7 \%$ & $\mathrm{I}, 007$ & $8.8 \%$ \\
\hline & Urban & 559 & $98.9 \%$ & 4,534 & $94.9 \%$ & 801 & $98.6 \%$ & 2,153 & $96.3 \%$ & 10,475 & $91.2 \%$ \\
\hline \multicolumn{12}{|l|}{ MDS } \\
\hline \multicolumn{2}{|l|}{ Unique patients } & 29 & & 624 & & 17 & & 73 & & 11,382 & \\
\hline \multicolumn{2}{|l|}{ Unique providers } & 19 & & 300 & & 10 & & 56 & & 748 & \\
\hline \multirow[t]{5}{*}{ Age, years } & $\begin{array}{l}\text { Minimum- } \\
\text { maximum }\end{array}$ & 20 & 85 & 0 & $85+$ & 6 & 81 & 1 & $85+$ & 0 & $85+$ \\
\hline & Mean & 62 & & 68 & & 57 & & 65 & & 77 & \\
\hline & SD & $\pm|5.3|$ & & \pm 14.99 & & \pm 19.28 & & \pm 13.64 & & \pm 12.36 & \\
\hline & Median & 68 & & 71 & & 62 & & 66 & & 79 & \\
\hline & IQR & 53 & 73 & 61 & 79 & 51 & 68 & 58 & 73 & 71 & 86 \\
\hline \multirow[t]{6}{*}{ Age-group, years } & $0-17$ & 0 & 0 & 5 & $0.8 \%$ & 1 & $5.9 \%$ & I & $1.4 \%$ & 39 & $0.3 \%$ \\
\hline & $18-34$ & 2 & $6.9 \%$ & 22 & $3.5 \%$ & 1 & $5.9 \%$ & I & $1.4 \%$ & 63 & $0.6 \%$ \\
\hline & $35-44$ & 2 & $6.9 \%$ & 13 & $2.1 \%$ & 0 & 0 & 2 & $2.7 \%$ & 101 & $0.9 \%$ \\
\hline & $45-64$ & 8 & $27.6 \%$ & 162 & $26.0 \%$ & 9 & $52.9 \%$ & 29 & $39.7 \%$ & 1,368 & $12.0 \%$ \\
\hline & $65-74$ & 13 & $44.8 \%$ & 172 & $27.6 \%$ & 3 & $17.6 \%$ & 23 & $31.5 \%$ & 2,431 & $21.4 \%$ \\
\hline & $75+$ & 4 & $13.8 \%$ & 250 & $40.1 \%$ & 3 & $17.6 \%$ & 17 & $23.3 \%$ & 7,380 & $64.8 \%$ \\
\hline Sex & Male & 21 & $72.4 \%$ & 377 & $60.4 \%$ & 7 & $41.2 \%$ & 36 & $49.3 \%$ & 6,187 & $54.4 \%$ \\
\hline & Female & 8 & $27.6 \%$ & 246 & $39.4 \%$ & 10 & $58.8 \%$ & 37 & $50.7 \%$ & 5,194 & $45.6 \%$ \\
\hline & Unknown & 0 & 0 & I & $0.2 \%$ & 0 & 0 & 0 & 0 & I & 0 \\
\hline Race & White & 18 & $62.1 \%$ & 453 & $72.6 \%$ & 12 & $70.6 \%$ & 54 & $74.0 \%$ & 8,401 & $73.8 \%$ \\
\hline & Black & 5 & $17.2 \%$ & 57 & $9.1 \%$ & 2 & $11.8 \%$ & 7 & $9.6 \%$ & 1,050 & $9.2 \%$ \\
\hline & Other & 6 & $20.7 \%$ & 114 & $18.3 \%$ & 3 & $17.6 \%$ & 12 & $16.4 \%$ & $|, 93|$ & $17.0 \%$ \\
\hline Ethnicity & $\begin{array}{l}\text { Not Hispanic or } \\
\text { Latino }\end{array}$ & 17 & $58.6 \%$ & 295 & $47.3 \%$ & 11 & $64.7 \%$ & 41 & $56.2 \%$ & 5,441 & $47.8 \%$ \\
\hline & Hispanic or Latino & 3 & $10.3 \%$ & 44 & $7.1 \%$ & 1 & $5.9 \%$ & 2 & $2.7 \%$ & 612 & $5.4 \%$ \\
\hline & Other & 9 & $31.0 \%$ & 285 & $45.7 \%$ & 5 & $29.4 \%$ & 30 & $41.1 \%$ & 5,329 & $46.8 \%$ \\
\hline Admission type & Urgent/emergent & 18 & $62.1 \%$ & 510 & $81.7 \%$ & 13 & $76.5 \%$ & 58 & $79.4 \%$ & 9,857 & $86.6 \%$ \\
\hline & Elective & 11 & $37.9 \%$ & 109 & $17.5 \%$ & 4 & $23.5 \%$ & 14 & $19.2 \%$ & $\mathrm{I}, 434$ & $12.6 \%$ \\
\hline & Trauma & 0 & 0 & 1 & $0.2 \%$ & 0 & 0 & 1 & $1.4 \%$ & 21 & $0.2 \%$ \\
\hline & Other/unknown & 0 & 0 & 4 & $0.6 \%$ & 0 & 0 & 0 & 0 & 70 & $0.6 \%$ \\
\hline Discharge status & Home & 25 & $86.2 \%$ & 399 & $63.9 \%$ & 14 & $82.4 \%$ & 28 & $38.4 \%$ & 7,775 & $68.3 \%$ \\
\hline & Transferred & 0 & 0 & 25 & $4.0 \%$ & 1 & $5.9 \%$ & 8 & $11.0 \%$ & 301 & $2.6 \%$ \\
\hline & SNF & 0 & 0 & 70 & $11.2 \%$ & 1 & $5.9 \%$ & 8 & $11.0 \%$ & 1,996 & $17.5 \%$ \\
\hline & Expired & 2 & $6.9 \%$ & 64 & $10.3 \%$ & 0 & 0 & 18 & $24.7 \%$ & 457 & $4.0 \%$ \\
\hline & Hospice & I & $3.4 \%$ & 57 & $9.1 \%$ & I & $5.9 \%$ & 11 & $15.1 \%$ & 744 & $6.5 \%$ \\
\hline & Other/unknown & 1 & $3.4 \%$ & 9 & $1.4 \%$ & 0 & 0 & 0 & 0 & 109 & $1.0 \%$ \\
\hline
\end{tabular}


Table S3 (Continued)

\begin{tabular}{|c|c|c|c|c|c|c|c|c|c|c|c|}
\hline \multirow[t]{2}{*}{$\begin{array}{l}\text { AML } \\
\text { No. of beds }\end{array}$} & \multirow[b]{2}{*}{$1-149$} & \multicolumn{2}{|c|}{$\begin{array}{l}\text { Single } \\
\text { antifungal } \\
\text { (posaconazole) }\end{array}$} & \multicolumn{2}{|c|}{$\begin{array}{l}\text { Single } \\
\text { antifungal } \\
\text { (not } \\
\text { posaconazole) }\end{array}$} & \multicolumn{2}{|c|}{$\begin{array}{l}\text { Multiple } \\
\text { antifungals } \\
\text { (including } \\
\text { posaconazole) }\end{array}$} & \multicolumn{2}{|c|}{$\begin{array}{l}\text { Multiple } \\
\text { antifungals } \\
\text { (not including } \\
\text { posaconazole) }\end{array}$} & \multicolumn{2}{|c|}{$\begin{array}{l}\text { No } \\
\text { antifungal }\end{array}$} \\
\hline & & 0 & 0 & 32 & $5.1 \%$ & 0 & 0 & 2 & $2.7 \%$ & $\mathrm{I}, 053$ & $9.3 \%$ \\
\hline & $150-249$ & I & $3.4 \%$ & 85 & $13.6 \%$ & I & $5.9 \%$ & 9 & $12.3 \%$ & $\mathrm{I}, 846$ & $16.2 \%$ \\
\hline & $250-349$ & 4 & $13.8 \%$ & 112 & $17.9 \%$ & 1 & $5.9 \%$ & 8 & $11.0 \%$ & 2,187 & $19.2 \%$ \\
\hline & $350-449$ & 4 & $13.8 \%$ & 99 & $15.9 \%$ & 3 & $17.6 \%$ & 10 & $13.7 \%$ & 2,097 & $18.4 \%$ \\
\hline & $450-549$ & 1 & $3.4 \%$ & 103 & $16.5 \%$ & 1 & $5.9 \%$ & 16 & $21.9 \%$ & $\mathrm{I}, 564$ & $13.7 \%$ \\
\hline & $550+$ & 19 & $65.5 \%$ & 193 & $30.9 \%$ & 11 & $64.7 \%$ & 28 & $38.4 \%$ & 2,635 & $23.2 \%$ \\
\hline \multirow[t]{4}{*}{ Geographic region } & West & 3 & $10.3 \%$ & 94 & $15.1 \%$ & $\mathrm{I}$ & $5.9 \%$ & 10 & $13.7 \%$ & 1,813 & $15.9 \%$ \\
\hline & Midwest & 2 & $6.9 \%$ & 75 & $12.0 \%$ & 2 & $11.8 \%$ & 9 & $12.3 \%$ & 2,192 & $19.3 \%$ \\
\hline & Northeast & 10 & $34.5 \%$ & 110 & $17.6 \%$ & 4 & $23.5 \%$ & 12 & $16.4 \%$ & 2,289 & $20.1 \%$ \\
\hline & South & 14 & $48.2 \%$ & 345 & $55.3 \%$ & 10 & $58.9 \%$ & 42 & $57.6 \%$ & 5,088 & $44.7 \%$ \\
\hline \multirow[t]{2}{*}{ Teaching } & Yes & 9 & $31.0 \%$ & 338 & $54.2 \%$ & 3 & $17.6 \%$ & 30 & $41.1 \%$ & 6,557 & $57.6 \%$ \\
\hline & No & 20 & $69.0 \%$ & 286 & $45.8 \%$ & 14 & $82.4 \%$ & 43 & $58.9 \%$ & 4,825 & $42.4 \%$ \\
\hline \multirow[t]{2}{*}{ Urban/rural } & Rural & 0 & 0 & 48 & $7.7 \%$ & 0 & 0 & 6 & $8.2 \%$ & 1,039 & $9.1 \%$ \\
\hline & Urban & 29 & $100 \%$ & 576 & $92.3 \%$ & 17 & $100 \%$ & 67 & $91.8 \%$ & 10,343 & $90.9 \%$ \\
\hline \multicolumn{12}{|l|}{ HSCT } \\
\hline \multicolumn{2}{|l|}{ Unique patients } & 109 & & 7,513 & & 228 & & 1,634 & & 4,736 & \\
\hline \multicolumn{2}{|l|}{ Unique providers } & 31 & & 175 & & 35 & & 71 & & 382 & \\
\hline \multirow[t]{5}{*}{ Age, years } & $\begin{array}{l}\text { Minimum- } \\
\text { maximum }\end{array}$ & 1 & $85+$ & 0 & $85+$ & 4 & 82 & 0 & 85 & 0 & $85+$ \\
\hline & Mean & 53 & & 53 & & 52 & & 43 & & 51 & \\
\hline & SD & \pm 16.48 & & \pm 17.52 & & \pm 15.63 & & \pm 22.28 & & \pm 22.48 & \\
\hline & Median & 57 & & 58 & & 55 & & 51 & & 57 & \\
\hline & IQR & 46 & 64 & 46 & 65 & 44.5 & 63 & 24 & 61 & 38 & 67 \\
\hline \multirow[t]{6}{*}{ Age-group, years } & $0-17$ & 4 & $3.7 \%$ & 470 & $6.3 \%$ & 8 & $3.5 \%$ & 326 & 20 & 687 & $14.5 \%$ \\
\hline & $18-34$ & 13 & $11.9 \%$ & 617 & $8.2 \%$ & 28 & $12.3 \%$ & 194 & $11.9 \%$ & 404 & $8.5 \%$ \\
\hline & $35-44$ & 8 & $7.3 \%$ & 622 & $8.3 \%$ & 21 & $9.2 \%$ & 153 & $9.4 \%$ & 329 & $6.9 \%$ \\
\hline & $45-64$ & 59 & $54.1 \%$ & 3,711 & $49.4 \%$ & 121 & $53.1 \%$ & 674 & $41.2 \%$ & I,864 & $39.4 \%$ \\
\hline & $65-74$ & 19 & $17.4 \%$ & 1,914 & $25.5 \%$ & 46 & $20.2 \%$ & 269 & $16.5 \%$ & 985 & $20.8 \%$ \\
\hline & $75+$ & 6 & $5.5 \%$ & 179 & $2.4 \%$ & 4 & $1.8 \%$ & 18 & $1.1 \%$ & 467 & $9.9 \%$ \\
\hline \multirow[t]{3}{*}{ Sex } & Male & 63 & $57.8 \%$ & 4,345 & $57.8 \%$ & 138 & $60.5 \%$ & 955 & $58.4 \%$ & 2,604 & $55.0 \%$ \\
\hline & Female & 46 & $42.2 \%$ & 3,168 & $42.2 \%$ & 90 & $39.5 \%$ & 679 & $41.6 \%$ & 2,132 & $45.0 \%$ \\
\hline & Unknown & 0 & 0 & 0 & 0 & 0 & 0 & 0 & 0 & 0 & 0 \\
\hline \multirow[t]{3}{*}{ Race } & White & 69 & $63.3 \%$ & 5,359 & $71.3 \%$ & 138 & $60.5 \%$ & 1,034 & $63.3 \%$ & 3,430 & $72.4 \%$ \\
\hline & Black & 6 & $5.5 \%$ & 873 & $11.6 \%$ & 18 & $7.9 \%$ & 196 & $12.0 \%$ & 539 & $11.4 \%$ \\
\hline & Other & 34 & $31.2 \%$ & $\mathrm{I}, 28 \mathrm{I}$ & $17.1 \%$ & 72 & $31.6 \%$ & 404 & $24.7 \%$ & 767 & $16.2 \%$ \\
\hline Ethnicity & $\begin{array}{l}\text { Not Hispanic or } \\
\text { Latino }\end{array}$ & 70 & $64.2 \%$ & 4,354 & $58.0 \%$ & 118 & $51.8 \%$ & 819 & $50.1 \%$ & 3,288 & $69.4 \%$ \\
\hline & Hispanic or Latino & 10 & $9.2 \%$ & 482 & $6.4 \%$ & 14 & $6.1 \%$ & 111 & $6.8 \%$ & 350 & $7.4 \%$ \\
\hline & Other & 29 & $26.6 \%$ & 2,677 & $35.6 \%$ & 96 & $42.1 \%$ & 704 & $43.1 \%$ & 1,098 & $23.2 \%$ \\
\hline Admission type & Urgent/emergent & 43 & $39.5 \%$ & 2,352 & $31.3 \%$ & 82 & $35.9 \%$ & 508 & $31.1 \%$ & 2,158 & $45.5 \%$ \\
\hline & Elective & 65 & $59.6 \%$ & 5,117 & $68.1 \%$ & 146 & $64.0 \%$ & 1,113 & $68.1 \%$ & 2,551 & $53.9 \%$ \\
\hline & Trauma & 0 & 0 & 2 & 0 & 0 & 0 & I & $0.1 \%$ & I & 0 \\
\hline & Other/unknown & I & $0.9 \%$ & 42 & $0.6 \%$ & 0 & 0 & 12 & $0.7 \%$ & 26 & $0.5 \%$ \\
\hline Discharge status & Home & 107 & $98.2 \%$ & 7,197 & $95.8 \%$ & 194 & $85.1 \%$ & 1,388 & $84.9 \%$ & 4,298 & $90.8 \%$ \\
\hline & Transferred & 1 & $0.9 \%$ & 53 & $0.7 \%$ & 4 & $1.8 \%$ & 32 & $2.0 \%$ & 67 & $1.4 \%$ \\
\hline & SNF & 0 & 0 & 92 & $1.2 \%$ & 0 & 0 & 27 & $1.7 \%$ & 203 & $4.3 \%$ \\
\hline & Expired & 1 & $0.9 \%$ & 62 & $0.8 \%$ & 25 & $11.0 \%$ & 150 & $9.2 \%$ & 80 & $1.7 \%$ \\
\hline & Hospice & 0 & 0 & 17 & $0.2 \%$ & 2 & $0.9 \%$ & 14 & $0.9 \%$ & 58 & $1.2 \%$ \\
\hline & Other/unknown & 0 & 0 & 92 & $1.2 \%$ & 3 & $1.3 \%$ & 23 & $1.4 \%$ & 30 & $0.6 \%$ \\
\hline No. of beds & $1-149$ & 0 & 0 & 12 & $0.2 \%$ & 0 & 0 & 0 & 0 & 90 & $1.9 \%$ \\
\hline & $150-249$ & 4 & $3.7 \%$ & 833 & $11.1 \%$ & 8 & $3.5 \%$ & 202 & $12.4 \%$ & 530 & $11.2 \%$ \\
\hline & $250-349$ & 4 & $3.7 \%$ & 421 & $5.6 \%$ & 9 & $3.9 \%$ & 65 & $4.0 \%$ & 460 & $9.7 \%$ \\
\hline & $350-449$ & 24 & $22.0 \%$ & 477 & $6.3 \%$ & 26 & $11.4 \%$ & 69 & $4.2 \%$ & 703 & $14.8 \%$ \\
\hline
\end{tabular}


Table S3 (Continued)

\begin{tabular}{|c|c|c|c|c|c|c|c|c|c|c|c|}
\hline \multirow[t]{2}{*}{ AML } & \multirow[b]{2}{*}{$450-549$} & \multicolumn{2}{|c|}{$\begin{array}{l}\text { Single } \\
\text { antifungal } \\
\text { (posaconazole) }\end{array}$} & \multicolumn{2}{|c|}{$\begin{array}{l}\text { Single } \\
\text { antifungal } \\
\text { (not } \\
\text { posaconazole) }\end{array}$} & \multicolumn{2}{|c|}{$\begin{array}{l}\text { Multiple } \\
\text { antifungals } \\
\text { (including } \\
\text { posaconazole) }\end{array}$} & \multicolumn{2}{|c|}{$\begin{array}{l}\text { Multiple } \\
\text { antifungals } \\
\text { (not including } \\
\text { posaconazole) }\end{array}$} & \multicolumn{2}{|c|}{$\begin{array}{l}\text { No } \\
\text { antifungal }\end{array}$} \\
\hline & & 5 & $4.6 \%$ & 531 & $7.1 \%$ & 8 & $3.5 \%$ & 134 & $8.2 \%$ & 767 & $16.2 \%$ \\
\hline & $550+$ & 72 & $66.1 \%$ & 5,239 & $69.7 \%$ & 177 & $77.6 \%$ & 1,164 & $71.2 \%$ & 2,186 & $46.2 \%$ \\
\hline \multirow[t]{4}{*}{ Geographic region } & West & 10 & $9.2 \%$ & 687 & $9.1 \%$ & 9 & $3.9 \%$ & 70 & $4.3 \%$ & 767 & $16.2 \%$ \\
\hline & Midwest & 15 & $13.7 \%$ & 1116 & $14.8 \%$ & 24 & $10.5 \%$ & 271 & $16.6 \%$ & 971 & $20.5 \%$ \\
\hline & Northeast & 31 & $28.4 \%$ & 2,740 & $36.5 \%$ & 93 & $40.8 \%$ & 630 & $38.6 \%$ & 855 & $18.0 \%$ \\
\hline & South & 53 & $48.7 \%$ & 2970 & $39.5 \%$ & 102 & $44.7 \%$ & 663 & $40.6 \%$ & 2,143 & $45.3 \%$ \\
\hline \multirow[t]{2}{*}{ Teaching } & Yes & 28 & $25.7 \%$ & 1,606 & $21.4 \%$ & 24 & $10.5 \%$ & 243 & $14.9 \%$ & 1,832 & $38.7 \%$ \\
\hline & No & 81 & $74.3 \%$ & 5,907 & $78.6 \%$ & 204 & $89.5 \%$ & I,391 & $85.1 \%$ & 2,904 & $61.3 \%$ \\
\hline \multirow[t]{2}{*}{ Urban/rural } & Rural & 0 & 0 & 143 & $1.9 \%$ & 0 & 0 & 6 & $0.4 \%$ & 247 & $5.2 \%$ \\
\hline & Urban & 109 & $100.0 \%$ & 7,370 & $98.1 \%$ & 228 & $100.0 \%$ & 1,628 & $99.6 \%$ & 4,489 & $94.8 \%$ \\
\hline \multicolumn{12}{|l|}{ GVHD } \\
\hline \multicolumn{2}{|l|}{ Unique patients } & 225 & & 2,192 & & 231 & & 769 & & 2,014 & \\
\hline \multicolumn{2}{|l|}{ Unique providers } & 69 & & 341 & & 37 & & 102 & & 495 & \\
\hline \multirow[t]{5}{*}{ Age, years } & $\begin{array}{l}\text { Minimum- } \\
\text { maximum }\end{array}$ & 0 & 74 & 0 & 85 & 12 & 78 & 0 & 77 & 0 & $85+$ \\
\hline & Mean & 51 & & 47 & & 50 & & 42 & & 49 & \\
\hline & SD & \pm 14.53 & & \pm 18.86 & & \pm 15.13 & & \pm 21.12 & & \pm 17.92 & \\
\hline & $\begin{array}{l}\text { Median Age-group, } \\
\text { years }\end{array}$ & 55 & & 52 & & 53 & & 48 & & 53 & \\
\hline & IQR & 42 & 62 & 36 & 61 & 42 & 62 & 24 & 59 & 37 & 62 \\
\hline \multirow[t]{6}{*}{ Age-group, years } & $0-17$ & 3 & $1.3 \%$ & 230 & $10.5 \%$ & 6 & $2.6 \%$ & 143 & $18.6 \%$ & 143 & $7.1 \%$ \\
\hline & $18-34$ & 39 & $17.3 \%$ & 289 & $13.2 \%$ & 38 & $16.5 \%$ & 124 & $16.1 \%$ & 297 & $14.7 \%$ \\
\hline & $35-44$ & 26 & $11.6 \%$ & 250 & $11.4 \%$ & 21 & $9.1 \%$ & 84 & $10.9 \%$ & 245 & $12.2 \%$ \\
\hline & $45-64$ & 120 & $53.3 \%$ & $\mathrm{I}, 085$ & $49.5 \%$ & 125 & $54.1 \%$ & 320 & $41.6 \%$ & 977 & $48.5 \%$ \\
\hline & $65-74$ & 37 & $16.4 \%$ & 323 & $14.7 \%$ & 40 & $17.3 \%$ & 95 & $12.4 \%$ & 298 & $14.8 \%$ \\
\hline & $75+$ & 0 & 0 & 15 & $0.7 \%$ & 1 & $0.4 \%$ & 3 & $0.4 \%$ & 54 & $2.7 \%$ \\
\hline \multirow[t]{3}{*}{ Sex } & Male & 144 & $64.0 \%$ & 1,268 & $57.8 \%$ & 132 & $57.1 \%$ & 451 & $58.6 \%$ & $\mathrm{I}, 144$ & $56.8 \%$ \\
\hline & Female & 81 & $36.0 \%$ & 924 & $42.2 \%$ & 99 & $42.9 \%$ & 318 & $41.4 \%$ & 870 & $43.2 \%$ \\
\hline & Unknown & 0 & 0 & 0 & 0 & 0 & 0 & 0 & 0 & 0 & 0 \\
\hline \multirow[t]{3}{*}{ Race } & White & 181 & $80.4 \%$ & 1,668 & $76.1 \%$ & 156 & $67.5 \%$ & 554 & $72.0 \%$ & I,455 & $72.2 \%$ \\
\hline & Black & 14 & $6.2 \%$ & 146 & $6.7 \%$ & 23 & $10.0 \%$ & 73 & $9.5 \%$ & 202 & $10.0 \%$ \\
\hline & Other & 30 & $13.3 \%$ & 378 & $17.2 \%$ & 52 & $22.5 \%$ & 142 & $18.5 \%$ & 357 & $17.7 \%$ \\
\hline \multirow[t]{3}{*}{ Ethnicity } & $\begin{array}{l}\text { Not Hispanic or } \\
\text { Latino }\end{array}$ & 157 & $69.8 \%$ & 1,295 & $59.1 \%$ & 148 & $64.1 \%$ & 449 & $58.4 \%$ & $\mathrm{I}, 147$ & $57.0 \%$ \\
\hline & Hispanic or Latino & 17 & $7.6 \%$ & 126 & $5.7 \%$ & II & $4.8 \%$ & 57 & $7.4 \%$ & 119 & $5.9 \%$ \\
\hline & Other & 51 & $22.7 \%$ & 771 & $35.2 \%$ & 72 & $31.2 \%$ & 263 & $34.2 \%$ & 748 & $37.1 \%$ \\
\hline Admission type & Urgent/emergent & 179 & $79.6 \%$ & 1,576 & $71.9 \%$ & 140 & $60.6 \%$ & 409 & $53.1 \%$ & 1,596 & $79.2 \%$ \\
\hline & Elective & 45 & $20.0 \%$ & 593 & $27.1 \%$ & 89 & $38.5 \%$ & 351 & $45.6 \%$ & 382 & $19.0 \%$ \\
\hline & Trauma & 1 & $0.4 \%$ & 5 & $0.2 \%$ & 0 & 0 & 1 & $0.1 \%$ & 8 & $0.4 \%$ \\
\hline & Other/unknown & 0 & 0 & 18 & $0.8 \%$ & 2 & $0.9 \%$ & 8 & $1.0 \%$ & 28 & $1.4 \%$ \\
\hline Discharge status & Home & 186 & $82.7 \%$ & I,702 & $77.6 \%$ & 160 & $69.3 \%$ & 526 & $68.4 \%$ & 1,518 & $75.4 \%$ \\
\hline & Transferred & 13 & $5.8 \%$ & 201 & $9.2 \%$ & 16 & $6.9 \%$ & 53 & $6.9 \%$ & 199 & $9.9 \%$ \\
\hline & SNF & 9 & $4.0 \%$ & 55 & $2.5 \%$ & 6 & $2.6 \%$ & 16 & $2.1 \%$ & 106 & $5.3 \%$ \\
\hline & Expired & 7 & $3.1 \%$ & 130 & $5.9 \%$ & 34 & $14.7 \%$ & 145 & $18.9 \%$ & 89 & $4.4 \%$ \\
\hline & Hospice & 3 & $1.3 \%$ & 39 & $1.8 \%$ & 9 & $3.9 \%$ & 14 & $1.8 \%$ & 30 & $1.5 \%$ \\
\hline & Other/unknown & 7 & $3.1 \%$ & 65 & $3.0 \%$ & 6 & $2.6 \%$ & 15 & $2.0 \%$ & 72 & $3.6 \%$ \\
\hline No. of beds & $1-149$ & 2 & $0.9 \%$ & 57 & $2.6 \%$ & I & $0.4 \%$ & 4 & $0.5 \%$ & 159 & $7.9 \%$ \\
\hline & $150-249$ & 10 & $4.4 \%$ & $27 \mid$ & $12.4 \%$ & 9 & $3.9 \%$ & 150 & $19.5 \%$ & 239 & $11.9 \%$ \\
\hline & $250-349$ & 12 & $5.3 \%$ & 218 & $9.9 \%$ & 12 & $5.2 \%$ & 31 & $4.0 \%$ & 331 & $16.4 \%$ \\
\hline & $350-449$ & 19 & $8.4 \%$ & 226 & $10.3 \%$ & 9 & $3.9 \%$ & 44 & $5.7 \%$ & 352 & $17.5 \%$ \\
\hline & $450-549$ & 20 & $8.9 \%$ & 165 & $7.5 \%$ & 9 & $3.9 \%$ & 40 & $5.2 \%$ & 247 & $12.3 \%$ \\
\hline & $550+$ & 162 & $72.0 \%$ & 1,255 & $57.3 \%$ & 191 & $82.7 \%$ & 500 & $65.0 \%$ & 686 & $34.1 \%$ \\
\hline
\end{tabular}

(Continued) 
Table S3 (Continued)

\begin{tabular}{|c|c|c|c|c|c|c|c|c|c|c|c|}
\hline \multirow{2}{*}{$\begin{array}{l}\text { AML } \\
\text { Geographic region }\end{array}$} & \multirow[b]{2}{*}{ West } & \multicolumn{2}{|c|}{$\begin{array}{l}\text { Single } \\
\text { antifungal } \\
\text { (posaconazole) }\end{array}$} & \multicolumn{2}{|c|}{$\begin{array}{l}\text { Single } \\
\text { antifungal } \\
\text { (not } \\
\text { posaconazole) }\end{array}$} & \multicolumn{2}{|c|}{$\begin{array}{l}\text { Multiple } \\
\text { antifungals } \\
\text { (including } \\
\text { posaconazole) }\end{array}$} & \multicolumn{2}{|c|}{$\begin{array}{l}\text { Multiple } \\
\text { antifungals } \\
\text { (not including } \\
\text { posaconazole) }\end{array}$} & \multicolumn{2}{|c|}{$\begin{array}{l}\text { No } \\
\text { antifungal }\end{array}$} \\
\hline & & 26 & $11.5 \%$ & 271 & $12.3 \%$ & 7 & $3.0 \%$ & 42 & $5.5 \%$ & 432 & $21.4 \%$ \\
\hline & Midwest & 24 & $10.6 \%$ & 327 & $14.9 \%$ & 12 & $5.2 \%$ & 114 & $14.9 \%$ & 358 & $17.8 \%$ \\
\hline & Northeast & 94 & $41.8 \%$ & 574 & $26.2 \%$ & 118 & $51.1 \%$ & 268 & $34.8 \%$ & 382 & $19.0 \%$ \\
\hline & South & 81 & $36.0 \%$ & 1020 & $46.5 \%$ & 94 & $40.7 \%$ & 345 & $44.9 \%$ & 842 & $41.8 \%$ \\
\hline \multirow[t]{2}{*}{ Teaching } & Yes & 42 & $18.7 \%$ & 743 & $33.9 \%$ & 16 & $6.9 \%$ & 203 & $26.4 \%$ & 929 & $46.1 \%$ \\
\hline & No & 183 & $81.3 \%$ & 1,449 & $66.1 \%$ & 215 & $93.1 \%$ & 566 & $73.6 \%$ & 1,085 & $53.9 \%$ \\
\hline \multirow[t]{2}{*}{ Urban/rural } & Rural & 3 & $1.3 \%$ & 76 & $3.5 \%$ & 0 & 0 & 5 & $0.7 \%$ & 148 & $7.3 \%$ \\
\hline & Urban & 222 & $98.7 \%$ & 2,116 & $96.5 \%$ & 231 & $100 \%$ & 764 & $99.3 \%$ & 1,866 & $92.7 \%$ \\
\hline
\end{tabular}

Note: All values are presented as number and percentages unless otherwise designated.

Abbreviations: AML, acute myeloid leukemia; GVHD, graft-vs-host disease; HSCT, hematopoietic stem-cell transplantation; MDS, myelodysplastic syndrome; SNF, skilled nursing facility.

\section{Publish your work in this journal}

ClinicoEconomics and Outcomes Research is an international, peerreviewed open-access journal focusing on health technology assessment, pharmacoeconomics and outcomes research in the areas of diagnosis, medical devices, and clinical, surgical and pharmacological intervention. The economic impact of health policy and health systems organization also constitute important areas of coverage. The manuscript management system is completely online and includes a very quick and fair peer-review system, which is all easy to use. Visit http://www.dovepress.com/testimonials.php to read real quotes from published authors. 